\title{
LOS SECRETOS DE LA TRADICIÓN: UNA LECTURA DE TRABAJOS DEL REINO DE YURI HERRERA
}

\author{
Raquel Velasco \\ Universidad Veracruzana \\ velasco_raquel@hotmail.com
}

RESUMEN: Con base en un paralelismo entre la estructura social y contextual que prevalecía en la Europa de la Edad Media con la tragedia que ha provocado la extensión del narcotráfico en México, este artículo aborda las resonancias de la prosa de Juan Rulfo en Trabajos del reino de Yuri Herrera. Esta novela corta se sostiene en el efecto de un secreto, propagado a través de distintas voces, capaces de delatar las contradicciones de la condición humana, con una profundidad que se sustenta en los ecos de la tradición literaria.

PALABRAS CLAVE: Herrera, Rulfo, novela corta, tradición literaria, narcotráfico

ABSTRACT: Based on a parallel between the social and contextual structure that prevailed in the Europe of the Middle Ages with the tragedy that has caused the spread of drug trafficking in Mexico, this article discusses the resonances of the Juan Rulfo's prose in Trabajos del reino of Yuri Herrera. This short novel is sustained in the effect of a secret, spread across different voices, able to reveal the contradictions of the human condition, with a depth that is based on the echoes of the literary tradition.

KEYWORDS: Herrera, Rulfo, short novel, literary tradition, drug trafficking

\section{Un contexto generacional}

En México, durante las últimas décadas, el abordaje literario de la realidad se ha detenido en recuperar la devastación dejada por las consecuencias del crimen organizado y aspectos relacionados con la frontera y la migración, dos de los iconos de la crisis enfrentada en este país. Tales temas, quizá por la frecuencia con la que son difundidos mediáticamente, han impactado de manera directa en la producción de las nuevas generaciones de escritores, pues el oscuro panorama referencial al que aluden sus obras no ha podido sustraerse a la expresión de esa violencia brutal que acongoja varios espacios urbanos y rurales, y que - como Hidra - regenera su funcionamiento de forma permanente.

En medio de esta dinámica literaria se encuentran las novelas y cuentos de un grupo de autores integrado por Élmer Mendoza (1949), Luis Humberto Crosthwaite (1962), Eduardo Antonio Parra (1965), Juan José Rodríguez (1970) y Heriberto Yépez (1974), entre otros, los cuales comparten — además de haber nacido la mayoría de ellos 
en la región norte de México- el confesarse admiradores de la prosa de Juan Rulfo y de buscar en su narrativa la nitidez del escritor jalisciense para retratar ambientes cercanos a una idea de país forjada en su frontera norte, donde algunos nacionalismos parecen enraizarse en cierta cultura nacional de extremos a veces controversiales.

No obstante, el homenaje no siempre se ha conseguido. De hecho, el crítico literario Rafael Lemus, en el artículo "Balas de salva: Notas sobre el narco y la narrativa mexicana", denomina a muchos de estos escritores como hijos bastardos de Rulfo. A este juicio se contrapuso la perspectiva de Eduardo Antonio Parra, quien en la polémica publicada en la revista Letras Libres a finales del año 2005, sostuvo que la llamada narrativa del norte no ha intentado retratar al narco en tonos pastel, como asegura Lemus, sino recuperar un contexto complejo por sus implicaciones y altamente expresivo en términos literarios. Sin embargo, más allá de lo expresado por Lemus y Parra, con agudos señalamientos por ambas partes, la narrativa del narcotráfico ha conseguido avisar sobre las repercusiones históricas, políticas, económicas y sociales de la emergencia de este factor.

De hecho, siguiendo algunas de las estrategias literarias de la llamada novela de crímenes, ampliamente estudiada por Gustavo Forero, muchas obras de los escritores contemporáneos - algunas con menos atributos estéticos que otras - pretenden ir a la médula del conflicto que ha acarreado la inserción del narcotráfico como parte de la lógica accional del estado mexicano, siguiendo el rastro de las carencias empáticas que favorecieron la explosión de una violencia sin límites, en un país cuyo imaginario se ha ido derrumbando por los excesos de gobernantes que sucumben ante sus deseos y el conformismo de ciudadanos acríticos frente a esta situación.

En medio de esta oferta editorial apareció la peculiar opera prima de Yuri Herrera (1970), Trabajos del reino, novela corta ganadora del Premio Binacional "Border of Worlds", que en 2005 fue publicada por el Fondo Editorial Tierra Adentro y en el año 2008 reeditada por Periférica, con la cual este autor nacido en el centro de México — en el estado de Hidalgo - a pesar de tocar los mismos temas de la generación referida y por edad ser incluido en las listas donde aparecen algunos de los autores apuntados, logra marcar una notoria diferencia respecto al abordaje literario del narcotráfico, precisamente por la materia de la que está hecha su obra.

En su narrativa, Herrera se preocupa más por recuperar las erratas del devenir que seguimos arrastrando como consecuencia de lo que él considera más los vuelcos de la condición humana que un fenómeno contextual, aspecto que aborda desde otros enfoques en sus siguientes novelas cortas: Señales que precederán al fin del mundo (2010) y La transmigración de los cuerpos (2013), y que junto con Trabajos del reino retoman las resonancias de una tradición literaria que permanece viva y revitalizan con un estilo muy personal - el arte de los nuevos creadores.

Estas páginas buscan recuperar las estrategias narrativas que modifican el cambio de tono en el tratamiento del contexto en Trabajos de reino y reflexionar sobre las resonancias que esta obra guarda de la prosa de Juan Rulfo, donde la particular voz de cada uno de los personajes propaga las tonalidades exactas para confrontar las contradicciones del alma. 


\section{Trabajos del reino: una novela corta de dimensiones épicas}

El comienzo de la primera novela de Yuri Herrera abre una clave que se repetirá casi como leitmotiv en la historia: "Él sabía de sangre, y vio que la suya era distinta. Se notaba en el modo en que el hombre llenaba el espacio, sin emergencia y con un aire de saberlo todo, como si estuviera hecho de hilos más finos. Otra sangre" (Herrera, 2008: 9). Esta frase es el punto de partida de una trama que parece ir caminando sola, donde dos personajes se encuentran en un momento crucial para sus vidas: Lobo descubre un nuevo sentido para aquellas palabras que creía conocer bien, y el Rey empieza a ser definido y revelado ante sí mismo y los demás por la interpretación de esas palabras cantadas por quien se convierte en su trovador.

Como ocurre en muchas novelas cortas, estos dos personajes son los pilares del relato y su vínculo se establece en el hilo de un secreto que debe ser guardado, sugerido desde las primeras páginas:

El briago se levantó y tambaleó hasta la mesa del Rey. Los suyos se pusieron alerta, pero el Rey se mantuvo impasible. El briago hizo un esfuerzo por enfocarlo y luego dijo:

-A usted lo conozco. He oído lo que dicen.

— ¿Ah sí? ¿Y qué dicen?

-El briago se rió. Se rascó una mejilla con torpeza.

—No, si no hablo de sus negocios, eso todo el mundo lo sabe... Hablo de lo otro.

Y se volvió a reír.

Al Rey se le oscureció la cara. Echó la cabeza un poco para atrás, se levantó. Hizo una seña a su guardia para que no lo siguiera. Se aproximó al briago y lo agarró del mentón. Aquél quiso revolcarse sin éxito. El Rey le acercó su boca a una oreja y dijo:

—Pues no creo que hayas oído nada. ¿Y sabes por qué? Porque los difuntos tienen muy mal oído.

Le acercó la pistola como si le palpara las tripas y disparó.

[...] El Rey se volvió al borracho que lo acompañaba:

-Y usté, ¿también quiere platicarme?

El borracho prendió su sombrero y huyó, haciendo con las manos gesto de No vi nada. (11-12)

El aludido conflicto no pronunciado del Rey es el que ha acongojado a muchos emperadores a lo largo de la historia: la carencia de un heredero de su propia sangre para hacerse cargo del reino que fundó. A partir de este secreto, que Ricardo Piglia muestra como una de las estrategias que sostiene la tensión narrativa de las novelas cortas, y de los componentes adicionales que se van sumando a la anécdota, simultáneamente el escritor hidalguense despliega en su obra una serie de elementos que permiten establecer un paralelismo entre la estructura social y contextual que prevalecía en la Europa de la Edad Media con la situación social que padece actualmente México.

La escena citada previamente marca el ritmo que habrá de mantenerse a lo largo del relato y muestra al protagonista las reglas del juego en el que ha decido participar para alcanzar esa nueva existencia que persigue como trovador. Su encomienda es contar las historias del imperio al que se ha integrado, en piezas musicales cuyo clímax 
repetitivo está determinado por las acciones de los personajes sobre los cuales canta, como se canta la lotería, ese juego de azar donde los personajes (el Joyero, el Doctor, el Gerente, el Pocho, el Gringo, el Padre, el Heredero, la Niña, la Cualquiera, la Bruja, el Periodista, el dos caras, etc.), aparecen en una constante sucesión de eventos en los que la suerte y las palabras dotan de posibilidades al rumbo de la anécdota.

Así, desde el quicio de un pacto no pronunciado, Lobo, al ingresar en la Corte, es bautizado como el Artista, por quien desde ese instante habrá de convertirse en su Rey - con todas las implicaciones que el significado de esta palabra tuvo en tiempos de respeto absoluto a esta figura de poder - y en cuyo palacio se van definiendo los roles que desempeña cada uno de los súbditos: "Era un rey, y a su alrededor todo cobraba sentido. Los hombres luchaban por él, las mujeres parían para él; él protegía y regalaba, y cada cual, en el reino, tenía por su gracia un lugar preciso. Pero los que acompañaban a este Rey no eran simples vasallos. Eran la Corte" (10).

La función de Lobo como compositor de narcocorridos obliga al protagonista a establecer una nueva relación con el mundo, determinada por lo que se espera de él en la Corte, la cual - como puede observarse - está construida con base en roles de actuación centrados en la particularidad de cada uno de los personajes, bajo una nomenclatura definida por el servicio que otorgan al hombre que ejerce un poder en apariencia ilimitado.

La lotería se canta, y así como propongo este juego para hablar de la tipificación e inestabilidad azarosa de los protagonistas en las dinámicas del narcotráfico descritos simbólicamente por Herrera - nuestro autor da vida a un lenguaje que recurre a alusiones musicales para exponer un mundo recuperado a través del oído; lo anterior proporciona a Trabajos del reino cierto lirismo que fortalece la ambigüedad de las metáforas activas en el relato, configuradas a su vez como secretos irrepetibles que susurran el pasado que cada quien lleva marcado en el cuerpo.

El Artista sabe leer en el rostro de las personas su historia individual, y en los espacios escucha el silencio para entender las historias de otra época; con esta habilidad proyecta cuidadosas alegorías en las que equilibra lo que debe ser obviado con las huellas de un contexto identificable para algunos. ${ }^{1}$

Lobo proviene de una familia donde el diálogo callado entre sus integrantes fue acumulando de palabras sus labios, convirtiéndose en una manera de subsistencia cuando en la calle aprendió a intercambiar rimas "por lástima y centavos" (15). Como cuenta la trama, un día su padre le puso un acordeón en las manos y fue así como comenzó a traducir en sonidos el forcejeo hostil que había captado en el movimiento del lugar donde vivía y cuyas reglas le parecían impenetrables, volviendo estribillos las

\footnotetext{
${ }^{1}$ Como señala Carlos Ávila: "En el libro de Herrera, el primer sentido de la alegoría desaparece; el otro, el doble sentido, es el único que está indicado, y va a depender de la interpretación del lector, porque es él quien está en la potestad de no tener en cuenta el sentido alegórico indicado por el autor: el lector asume una posición ante la obra y decide sobre ella. Si bien es cierto que Trabajos del reino tiene un sentido alegórico irrefutable, no podemos negar que está indicado de una manera irremediablemente sutil. No es casual que el autor haya optado, para contar su historia, por la forma de la fábula, justo el género que más se acerca a la alegoría pura: en ella, el sentido literal de las palabras tiende a borrarse por completo" (156157).
} 
palabras que aparecían en los carteles, en los diarios de las esquinas, en los letreros; haciendo estribillos con la información a la que tenía acceso y recomponiendo esas palabras en nuevas imágenes. Así comenzó a cantar en las cantinas y a descubrir también la función de cada ritmo para alentar sentimientos en quienes escuchaban su música. Así descubrió su profesión antes de que sus padres lo abandonaran tras irse al otro lado y él se convirtiera en un hijo de migrantes sin promesas de familia. Una historia más de frontera que Herrera esboza de forma tan eficiente que no tiene que entrar en detalles, sino solo sostenerse en lo que por muchas veces repetido, la mayoría de los lectores son capaces de construir mediante sus propios marcos de sentido.

Interpretar es una forma de actuar y eso hace el escritor cuando descifra las señales de un mundo contradictorio, y en la literatura cada apunte es una sugerencia de algo más. El protagonista de Trabajos del reino es un aprendiz de personalidades y de ciclos que se "puso a escribir canciones de cosas que le pasaban a otros. [...] Pero era una repetición lo suyo, un espejo de la vida que le contaban. Aunque tenía la sospecha de que algo más podía hacer con las canciones, ignoraba cómo arrojarse, porque ya todo estaba dicho, y entonces qué caso. Apenas quedaba esperar, continuar, esperar. ¿A qué? Un milagro" (17-18).

Lobo alude a esa reinterpretación que se resiste, de los días sin luz para atrapar una verdad que puede olerse en el aire, además del conflicto estético, moral y ético que enfrentan los artistas: crear sobre lo que ya carece de orientación semántica por el agotamiento de las proyecciones que arroja nuestro entorno y la necesidad de fundar un nuevo significado que nos dé la oportunidad de volver a entender las cosas.

¿Cómo hacerlo?, parece preguntarse incesantemente el creador. En esa interrogación, el lector comprende que va a emprender junto con el Artista un trayecto para revelar no solo los secretos de la historia que le será contada, sino los misterios individuales que cada uno confronta desde su propia aproximación al mundo que es representado en la obra de arte.

De este modo, comienza a correr con rienda suelta esta trama donde los ambientes son un pretexto para expresar que los lugares representan siempre lo mismo en las historias de poder, y que lo único que cambia es el decorado. Esto ocurre también en el plano social. El México descrito por Herrera - sin enunciar la denominación de una nación específica ni de una actividad determinada, como podría ser el narcotráfico - se ve en la descripción de unos usos y costumbres señoriales y en vasallos semejantes a los que interactuaban durante la Edad Media cuando Europa vivía el lado oscuro del feudalismo.

En la narrativa del escritor hidalguense, las palabras significan por ausencia; reclaman volver a su origen en la acompasada recuperación de sonidos, gestos e imágenes; su sentido está dado en un contexto donde las palabras tristemente han ido perdiendo su eficacia entre personas que decidieron volverse sordas para no escuchar nada más sobre el ruido estridente de una violencia ininterrumpida, retomada masivamente como si fuera información, cuando esta actúa a favor del régimen en el poder, en tanto herramienta de sometimiento entre la gente al propagar el miedo. Ese ánimo es el que Herrera combate al atravesar los temas mediante una condensación de 
elementos que dotan al argumento de lo necesario para delatar una circunstancia, sin recurrir a las imágenes que por gastadas dejaron de significar.

Paralelamente, en la función del Artista, Herrera retoma la controversia provocada por los narcocorridos y el porqué, tanto en la novela como en el mundo externo a la misma, de que haya sido prohibida su difusión legal como parte de la doble moral imperante, pues en el clandestino monopolio discográfico, este género musical se vende sin ningún tipo de censura, impulsando desde la marginalidad la construcción de valores sumergidos en las exigencias de pequeños cotos de poder, que intentan extender a cualquier precio su ámbito de repercusión, activando un círculo vicioso de complicidades y traiciones, en el que ha quedado inserta la trayectoria del dinero proveniente del narcotráfico y la estructura social que esta genera, donde todos hacen lo que el Rey les pide, porque en algún momento les llegaron a su muy personal precio o no pudieron combatir de ningún modo las amenazas que recibieron:

—Ya es hora — dijo—, trépese y pídale a los muchachos que lo acompañen.

El Artista se levantó con susto y caminó al escenario. [...] Se colocó entre los músicos, les pidió Ái nomás me siguen, y se lanzó. No era una historia nueva, pero nadie la había cantado. La había hallado a preguntas muchas sólo para escribirla y regalársela al Rey. Hablaba de sus agallas y de su corazón, puestos a prueba a mitad de una lluvia de plomo, y con final feliz no sólo para el Rey sino también para los jodidos que siempre cuidaba. Bajo aquella inmensa bóveda la voz se le dilataba con un cuerpo que jamás había cobrado en las cantinas. Cantó la historia con la fe que se cantan los himnos y con la certeza de los pregones, pero, más que todo, la hizo sentir pegajosa, para que la gente la aprendiera con la cintura y las piernas y pudiera repetirla después.

$\mathrm{Al}$ acabar, el gentío le prodigó chiflidos y aplausos, los músicos elegantes le palmearon la espalda y los Señores que acompañaban al Rey asintieron gustosos y pararon la trompa (quiso convencerse el Artista): con envidia. Bajó del escenario para ir a presentar sus respetos. El Rey lo miró a los ojos y el Artista inclinó la cabeza.

-Yo le supe el talento en cuanto lo vi - dijo el Rey, que, se conocía, no olvidaba un rostro-. ¿Así le salen todas, Artista?

- Se le hace la lucha, señor — balbuceó el Artista. bien. [...]

-Bueno, pues no se agüite, escriba, péguese aquí con los buenos y le va a ir

El Artista volvió a inclinarse y siguió al hombre con ganas de echarse a llorar, ciego de luces y de futuro. (24-25)

El Rey comparte con Lobo la capacidad de conocer los deseos más íntimos de las personas con solo observarlas, herramienta fundamental para volverse el señor del grupo que domina, donde la vida es un valor de cambio.

Como ocurría en la Edad Media y en algunas culturas de anclaje arcaico, esta situación a la que es reducida el hombre, en tanto cuerpo en permanente transacción involuntaria, en Trabajos del reino es clara respecto al rol que desempeñan las mujeres. Sin embargo, la aproximación de Herrera no involucra un juicio de género; su tipificación femenina está vinculada a una descripción contextual respecto a lo que se ha dicho en relación con el papel que ocupan las mujeres —o que son obligadas a teneral interior de los cárteles, es similar al que se les atribuía en la instauración de los reinos — desde las primeras manifestaciones de esta organización social- como responsables de garantizar la continuidad de una estirpe mediante la descendencia. 
Otro aspecto de ese tipo de violencia es el ejercido por algunas madres al ofrecer a sus hijas como prostitutas al servicio de hombres que pueden proporcionarles el sustento económico. Es el caso de La Bruja, que ha entregado al Rey a la Cualquiera y tiene el plan de que esta engendre el tan negado heredero natural, bajo una argumentación que parece ser la de un cuento muchas veces contado, reproducido en versiones rosa transmitidas por televisión, que no han hecho sino engañar sobre la posibilidad que tienen las mujeres de hacerse de un futuro más prometedor a través de la explotación de sus virtudes físicas:

La Bruja describió una parábola enérgica con una mano y tiró al suelo a la Cualquiera de una bofetada. [...]

— ¿Pero qué carajo es lo que quieres? ¿No ves que se nos va el último tren? ¿Para esto he esperado tanto tiempo?

La soltó con un gesto de cansancio. Luego le tomó las manos y, más dulce, dijo:

— ¿Qué hay allá? Basura. Aquí vas a tenerlo todo, nomás que componga a ese hombre. Espera un poquito más. Cuando la sangre rica que le doy arregle su semilla, tú también tienes que estar lista. Aun si el maldito pájaro no sirve voy a encontrar la manera de regalarte todo esto.

— ¿Y yo a qué hora dije que me interesaba este cochinero? — dijo la Cualquiera, cabizbaja aún. [...]

—Tampoco vi que le hicieras el feo — dijo_- así es que para mí que sí estás interesada, y si no, de cualquier manera ya estamos metidas hasta el cuello. (76-77)

El párrafo menciona los pactos irrompibles con los señores todopoderosos, pero también habla del talón de Aquiles que todos escondemos. El afán de tener cosas que de otro modo no podría conseguir la Cualquiera, la necesidad de la Bruja por salir de la pobreza, la exigencia de un hijo y la imposibilidad del Rey para engendrarlo, la inicial pretensión de fama y dinero del Artista, son ejemplos de esos deseos que nos llevan a transgredir los límites. En ese drama oculto que guardan nuestros anhelos y el afán de lograrlos a cualquier precio radica la estructura de un secreto más profundo que subyace en esta novela, cuyas verdades impronunciadas encuentran resonancia en esa búsqueda íntima que guía los pasos de cada uno de los lectores.

El Artista observa el peso del tirano en la gente y las ciudades que invariablemente terminan ultrajadas tras su presencia; conforme ve y oye, Lobo va traduciendo sus experiencias al lenguaje de la música, y luego de volver suya la necesidad de venganza, propaga, en una pieza que tenía como objetivo enaltecer a su protector, la verdad callada sobre la imposibilidad del Rey para dejar descendencia, precipitándose su derrota por la exhibición de poca hombría que encierra simbólicamente este hecho, que no queda explícito. Tal confrontación entre el Artista y el Rey establece de forma simultánea la separación emocional entre los protagonistas del relato, cuyas sangres - se confirma - responden a pulsiones diferentes.

Paralelamente, el declive del Rey muestra la lucha respecto al derecho sobre un territorio, pues en el sistema de hacerse de justicia y riqueza por mano propia hay muchos que están a la espera de una oportunidad. Esa redistribución constante del poder y el territorio, como ocurría en la Edad Media, es lo que genera innumerables disputas sobre la legitimidad de lo ostentado y propicia los violentos altercados entre grupos dirigidos por distintos líderes. 
Ya he señalado que en la construcción del universo simbólico de Trabajos del reino hay una estructura social que se asemeja a los arcaicos regímenes de poder, donde sus participantes - motivados por imaginarios, creencias o cierta violencia que impacta las decisiones de un grupo de personas - establecen un particular orden de vasallaje entre señor y súbditos, que responde a cualidades específicas.

En este sentido, aunque la novela no está exenta de referencialidad oculta, a través de los ojos del Artista descubrimos cómo existen distintivos para mostrar al enemigo responsable de su desgracia; marcas acentuadas en los cuerpos mutilados o en el tipo de acciones desarrolladas para generar el miedo en los oponentes, e imponer superioridad a través de recursos encaminados a despertar el terror. Esto recuerda la manera en que la correcta utilización del poder de la imagen servía para debilitar a ejércitos completos. La reina Isabel la Católica, con su sola presencia, rendía ciudades sin siquiera pisar el campo de batalla, solo luciendo el estandarte con el que se distinguía su campaña militar, afectando el ánimo de sus pobladores con el rumor de sus triunfos anteriores y el presagio de saberse perdidos ante tan soberana figura. ${ }^{2}$

Asimismo, Trabajos del reino exhibe la función de la iglesia y cómo esta ha actuado en tanto fuerza intermediaria no solo de la fe y la relación con lo divino, sino respecto a los negocios materiales en los que participa al legalizar dinero ilícito. Tampoco se trata de algo nuevo. Ha sido ampliamente documentado cómo se enriqueció la Iglesia Católica durante la Edad Media gracias a la venta de terrenos celestiales a cambio de predios en este mundo y de riquezas por el perdón de los pecados.

La manera de narrar de Yuri Herrera es coherente y organizada en los distintos planos que se unen en la confección de su obra, gracias a que las imágenes se sostienen en una trama y no viceversa, cualidad de muchas novelas cortas que con ingenio logran concentrar varios significados en un concepto, lo cual ayuda al autor a dar una nueva lectura de los elementos medulares de la condición humana, que permanecen en un desarrollo casi circular en las sociedades, para guiar otras formas de entender sus contradicciones, sin caer en trampas contextuales.

Para establecer este efecto de las palabras en la construcción de las verdades que funcionan en la interpretación de mundos que mucho tienen de particular, Herrera incluye como habitante del palacio a un personaje denominado el Periodista, el cual no solo se encargará de difundir masivamente las canciones del Artista y, por tanto, el contenido de las mismas, sino de enseñar a Lobo cómo en la literatura las palabras multiplican su significado. Esto permite que una sola frase pueda cambiar la percepción de las cosas, revelando aquello que permanece oculto en el uso habitual de conceptos que — podríamos creer — jamás cambian su orientación semántica.

\footnotetext{
2 Ana Isabel Carrasco menciona que cuando Isabel de Trastámara peleaba junto con su esposo Fernando de Aragón contra Juana de Portugal, por la sucesión regia de Castilla, pugna a la que condujo precisamente - la conocida impotencia del rey Enrique IV, fue definitoria la rendición del castillo de Burgos como resultado del sitio impuesto a la población. Sin embargo, las crónicas señalan que el "10 de enero de 1476 entraba la reina en la ciudad. Según Serrano, fue una entrada triunfal, desplegándose toda la pompa que un concejo castigado económicamente podía desplegar: regocijos públicos, música y danza, juegos. Hay que tener en cuenta, además, que era la primera vez que la reina entraba en Burgos, ciudad que pasaba por ser la más importante del reino (cabeza de Castilla y cámara real), o, al menos, la más «honrada»"(193-194).
} 
Dentro de las cortes siempre han habido artistas. Es imposible olvidar a familias como los Medici o los Borgia, que impulsaron prolíficos movimientos en la historia del arte, pues independientemente del mecenazgo al que servían, muchos creadores fueron capaces de leer el mundo que los rodeaba y transformarlo en una nueva interpretación para las mitologías de una época. Lo que el artista dice fija la memoria sobre esa corte a la que pertenece, ${ }^{3}$ pues su función es distinguir al Rey y sus vasallos de los de otros reinos. El trovador de Herrera debe elogiar en cada canción las aventuras y logros de la organización criminal a la que se integra; su actividad se asemeja a la que dio origen a la manifestación literaria denominada como mester de juglaría:

No hubo cortesano a quien negara sus dones, pero el Artista contaba la hazaña de cada cual sin olvidarse de quién la hacía posible. Si eres chilo, porque te lo permite el Rey. Sí, qué valiente eres, porque te inspira el Rey. Sólo dejaba de mencionarlo cuando escribía letritas de amor pedidas por algún cortesano a susurros. Después le palmeaban la espalda o lo aferraban del cuello y decían: Lo que se le ofrezca, Artista.

[...]

Solo dos de la Corte no le pidieron corrido. Y dónde que se lo merecían. [...] Cuando le dijo al Heredero que ya casi tenía su historia lista, le contestó:

-Después. - Apretó la mandíbula como amarrando las palabras que seguían y nomás repitió: -Después.

$[\ldots]$

Y el otro que no quiso, el que le cuidaba el nombre al Rey, el Periodista, le dijo:

-Mejor no, si usted me pinta el retrato me vuelvo inútil. Imagínese: cuando allá fuera se enteren de dónde ando metido, ¿quién me va a creer que no sé nada?

El Artista comprendió. Debía dejarlo cumplir su trabajo. Para entretener a los necios con mentiras limpias el Periodista tenía que hacerlas parecer verdades. Las noticias verdaderas eran cosa de él, materia de corrido, y había tantas por cantar que bien podía olvidar las que no servían al Rey. (34-36)

Cito en extenso este apartado de la novela porque se trata de uno de los ejemplos más claros de la manera en que opera en Trabajos del reino la subversión de valores prevaleciente en los lugares que viven bajo el régimen del crimen y — por tantodominados por señores, que en la lógica contemporánea actúan como aquellos hombres que alguna vez instauraron el régimen feudal.

Ahora bien, en el paralelismo que propone Herrera entre la función del Artista y el Periodista en el interior de la corte, puede destacarse otra sugerencia del autor: que el arte, como la noticia, es un medio de difusión corrompible si sirve a dudosos propósitos, pues cuando la calidad de las palabras o imágenes permite alcanzar altos niveles simbólicos, donde forma y contenido hacen una amalgama de sentido, se vuelve peligrosa la causa a la que se vende. Prueba de ello es la repercusión de los mejores narcocorridos, que han ofrecido la posibilidad de obtener la inmortalidad a quienes viven en el margen, mediante la difusión de sus hazañas con mecanismos que responden a una estética específica. ${ }^{4}$

\footnotetext{
${ }^{3}$ Muestra de ello es el esperpéntico retrato de "La familia de Carlos IV" realizado por Francisco de Goya en 1800 , el cual ha quedado como testimonio gráfico de una estirpe en decadencia.

${ }^{4}$ Dice al respecto Enrique Flores: “[...] los narcocorridos forman parte de una tradición poética popular - la de los antiguos romances de ciego, las baladas de crímenes y bandoleros, o de ajusticiados.

La idea que me gustaría sostener es la de «la puesta en escena de lo real». O, en vista de las perfomances del narco, la puesta en escena en lo real. Porque lo que se expone, lo que se exhibe
} 
En este sentido, una más de las vueltas de tuerca al orden clásico, tras la imposición del narcotráfico, radica en el propósito de explotar la idea de que un contenido repetido infinidad de veces, se vuelve realidad en las mentes y corazones de quienes aprenden en las vidas cantadas de otros que, sin importar el riesgo de muerte, solo rompiendo la ley es posible salir del ambiente de inmundicia al que han sido condenados por siglos de malos gobiernos, y que solo a partir de ese esfuerzo podrá existir un cambio en la ruleta que los sumergió en el dolor de la inhumana pobreza; de ahí el desequilibrio de fuerzas actual que se vive en México.

En Trabajos del reino, el Periodista deja otra lección al Artista: "si uno disfruta las palabras es como pistear con el oído" (36). Las alusiones a la música como elemento medular en la asociación lingüística es una constante en el carácter narrativo de Yuri Herrera, quien, como su trovador, recuenta las historias que escucha y rastrea la verdad oculta en lo que se repite una y otra vez sin mucha conciencia del sentido profundo que hay en las palabras, como ocurre con un tornamesa que nunca cambia su mecanismo, solo de disco. Así, el escritor también exhibe el cosmos filosófico de esta novela corta colmada de guiños para el lector, y establece un paralelismo entre el devenir de las acciones y la ruptura que ha provocado en la estructura convencional la pérdida de Dios como referente absoluto:

¿Qué era eso de que uno ya había estado aquí, en otra vida? ¿Que Dios le tenía a cada cual reservado un deber de siglos? Por un tiempo, la idea había desvelado al Artista, hasta que halló en el Palacio una imagen que lo liberó: un aparato exquisito, un tornamesa con punta de diamante para acetatos treintaitrés, perteneciente al Joyero, quien un fin de semana olvidó apagarlo $y$, cuando se percató dos días después la máquina ya no servía.

Eso es, pensó el Artista, eso somos. Un aparato del que nadie se acuerda, sin propósito. Quizá Dios había puesto la aguja, pero luego se había ido a curarse la cruda. El Artista ya estaba consciente de que no había nadie sobre el cielo o bajo el suelo para protegerlo, que cada quien para su santo; pero ahora, en la Corte, se le aclaraba que uno podía gozarse antes de que el diamante se hiciera polvo. No esperar nomás. (27-28)

Este cambio de paradigma ha provocado una vertiginosa movilización social. Las reglas pueden ser transformadas luego de ese viraje de concepciones donde cada quien tiene la posibilidad de modificar su destino, sin temor a perder la gracia de un dios carente de sustento científico y bastante ausente en tiempos de dificultad, si de fe se trata su existencia. Esa es la enseñanza principal que prodiga al Artista el encuentro con el Rey.

Simultáneamente, el escritor de esta novela corta exhibe un sistema circular donde todo orden es perentorio, en el que un descuido acaba con la continuidad y la vida del instrumento que ejerce el poder se vuelve finita. De este modo, aparece un reino de imágenes, el cual — paradójicamente - se mueve a partir de reglas bien definidas, a las que sus pobladores deben ceñirse, aunque no estén de acuerdo con ellas, pues la sola aceptación de someterse a esas leyes conlleva la declaración de obedecer sin cuestionar los mandatos.

morbosamente es una «puesta en escena» simbólica que alude a un código esotérico, pero que, en última instancia, se refiere a «lo real» que es lo imposible, lo que no podemos soportar" (11). 


\section{El eco de Juan Rulfo en Trabajos del reino}

Si bien la frontera, la migración y el narcotráfico han sido abordados desde aproximaciones que platean acercamientos realistas de estos contextos, y muchos de ellos se dicen inspirados en la prosa de Juan Rulfo, Yuri Herrera — supongo que sin proponérselo siquiera - aprende del escritor jaliciense a otorgarle un nuevo sentido a conceptos que han ido perdiendo su significado.

En Trabajos del reino, Herrera recupera la capacidad de las palabras para reordenar nuestras concepciones, su peso específico, así como la actitud del Artista frente a ellas:

Tantas letras juntas. Suyas. Puestas ahí sin otra cosa que hacer que fecundar la testa. Son. Muelen la hoja entre rodillos de insomnio, avisan, hurgan la blancura baldía en el papel y en el mirar. ¿Y qué había sido la hoja sino un trasto del jale, como el serrucho si armara mesas, como la fusca si arreglara vidas? Qué, pero nunca este despeñadero de arena con brío y propósitos a saber. Tantas letras ahí. Son. Son un destello. Cómo se empujan y abrevan una de otra y envuelven al ojo en un borlote de razones. Y qué si perfectas, igual rejegas, ya se incriminan con miedo al desarreglo: palabras. Tantas palabras. Suyas. Bronca de signos que se atan. Son una luz constante. Son. (Él ya sabía de los libros, pero lo repelían, como una patria que no invitaba. Y ahora se ha dejado llevar de la mano hasta el acopio de secretos. Una luz constante.) Un resplandor diverso cada una, cada una diciendo el nombre verdadero a su modo. Hasta las más mentirosas hasta las más veleidosas. Ajá. No están ahí nomás para fecundar la testa. Son una luz constante. El rumbo a otros cartones, lejos de ahí. El descenso a oídos ocultos, ahí. (Como los bichos que lo pueblan.) No. No están para nomás entretener la vista ni alimentar la oreja. Son una luz constante. Son un faro que se derrama sobre las piedras a su merced, son una linterna que se pasea, se detiene, acaricia la tierra y le descubre cómo acabalar el servicio que le ha tocado. (39-40. Las cursivas me pertenecen)

Las palabras permanecen como huella indeleble de una tradición que siempre puede ser revitalizada. Las palabras son una luz constante y Herrera lo repite cuatro veces como si fuera un estribillo en medio de la oscuridad; son una luz constante, cuyo resplandor quizá sea el causante de las migrañas que padece el Artista.

Trabajos del reino parece haberse iniciado tiempo atrás del comienzo del relato, esto provoca en el lector la sensación de que algo ha venido pasando, de lo cual debe enterarse pronto. Este vilo es conseguido por el escritor mediante la construcción de oraciones ambiguas que abren una pausa en la historia, gracias a un casi imperceptible cambio de ritmo en la prosa: a su vez, describe con detalle los elementos que condensan el significado profundo de la trama más allá de lo trágico y así — gradualmente - nos vamos enterando de lo que sucede; una estrategia narrativa clara en el inicio de Pedro Páramo (1955) de Juan Rulfo, donde la selección de las palabras nos regala uno de los principios más tensos de la literatura: "Vine a Comala porque me dijeron que acá vivía mi padre, un tal Pedro Páramo. Mi madre me lo dijo. Y yo le prometí que vendría a verlo en cuanto ella muriera" (1984: 3). Esas pocas frases por sí solas casi conjugan un cuento por el antes y después que ofrece, y muchos de los momentos de Trabajos del reino parecen tener esa complejidad, de ahí la acumulación de significados por comprender en cada párrafo de la obra. 
Además de la historia de orfandad, detrás de los relatos de Rulfo y Herrera está el detenimiento de ambos en observar una serie de miserias, donde la literatura es una forma de catarsis, en tanto con el ejercicio de su pluma las tragedias se convierten en algo más. Probablemente en una nueva versión de esos mitos que se repiten cíclicamente. Se ha dicho que Juan Preciado es una reconstrucción de Telémaco, ${ }^{5}$ arquetipo del huérfano que Herrera vuelve a presentar desde otra óptica. Si con Rulfo tenemos el personaje que regresa a su tierra, en Trabajos del reino está el que es abandonado por sus padres. El huérfano de Pedro Páramo es víctima de los excesos del cacicazgo; el Artista de Herrera primero de la migración y el sueño americano y después de la redes que tiende el narcotráfico con luces de oropel a quienes han quedado en la orfandad.

Otro hilo en común entre la narrativa de Rulfo y Herrera es la habilidad de los dos autores para recrear la crudeza de ambientes devastados sin un despliegue de los rasgos característicos del lenguaje de la violencia. Por el contrario, Herrera recurre a la enseñanza de Rulfo para hacer de palabras que aparentan ser cotidianas una sucesión acústica semejante a la oralidad, que nada tiene de referencial. Así también privilegia las deliberadas intenciones de los silencios dispuestos para generar una cadencia específica en el ritmo de los relatos, a partir de un detalle impresionante en la escritura, que permite pasar por natural la complejidad inserta en el armado de las distintas voces que cohabitan en el relato.

En El llano en llamas (1953) y Pedro Páramo, así como en Trabajos del reino, hay un vínculo entre la pobreza y la perdición, una recuperación de cómo en México desde hace mucho tiempo llueve sobre mojado; de las imágenes provenientes de pueblos desolados no solo por cacicazgos y capos criminales, sino por las guerras entre iguales; y la obediencia mansa al poder factual, muchas veces al margen del Estado, muchas veces impulsada desde la iglesia.

Herrera también aprende de Rulfo cómo hacer de una caracterización geográfica la explicación de un estado existencial del alma, al describir ambientes que nunca se sienten como fotografías de un espacio o de momentos reconocibles, pero que al intercalar vacíos cualitativos dan la oportunidad al lector de culminar la escena con ayuda de su propio imaginario.

Como ocurre con varios protagonistas del universo rulfiano, en una escena de la novela corta de Herrera Lobo se pregunta por qué reaccionan los personajes con tanta

\footnotetext{
${ }^{5}$ En La nueva novela hispanoamericana, Carlos Fuentes es el primero en hacerlo: "No sé si se ha advertido el uso sutil que Rulfo hace de los grandes mitos universales en Pedro Páramo. Su arte es tal, que la trasposición no es tal: la imaginación mítica renace en el suelo mexicano y cobra, por fortuna, un vuelo sin prestigio. Pero ese joven Telémaco que inicia la contra-odisea en busca de su padre perdido, ese arriero que lleva a Juan Preciado a la otra orilla, la muerta, de un río de polvo, esa voz de la madre y amante, Yocasta-Eurídice, que conduce al hijo y amante, Edipo-Orfeo, por los caminos del infierno, esa pareja de hermanos edénicos y adánicos que duermen juntos en el lodo de la creación para iniciar otra vez la generación humana en el desierto de Comala, esas viejas virgilianas -Eduviges, Damiana, La Cuarraca-, fantasmas de fantasmas, fantasmas que contemplan sus propios fantasmas, esa Susana San Juan, Electra al revés, el propio Pedro Páramo, Ulises de piedra y barro... todo este trasfondo mítico permite a Juan Rulfo proyectar la ambigüedad humana de un cacique, sus mujeres, sus pistoleros y sus víctimas y, a través de ellos, incorporar la temática del campo y la revolución mexicanos a un contexto universal" (16).
} 
calma frente a la rabia acumulada tras eventos marcados por la injusticia; la interrogación lleva al lector a averiguar cómo la violencia en exceso puede provocar esos estados de aparente inmovilidad y la decadencia anímica de algunos pueblos.

Tras el asesinato del Periodista, Lobo siente "la necesidad de no permitir que sucedieran más cosas sin que metiera las manos" (104), una referencia a lo que pasa en contextos semejantes - en el corazón de muchos artistas. Herrera adquiere un compromiso personal en su escritura acudiendo a una técnica narrativa que expresa en voz de su trovador: "Todo era cosa de sumar uno y uno, de poner una piedra sobre otra, para que las preguntas se respondieran. Él podía hacerlo y contar a todo mundo, pero sintió un gran fastidio, se dio cuenta de que no le interesaba en lo más mínimo revelar la intriga, que se trataba de meros incidentes de algo más definitivo que ya comprendía" (121). Su objetivo es encontrar la manera de compartir secretos sin pronunciarlos, para que cada lector obtenga sus propias interpretaciones sobre la función de los mismos.

Como ha ocurrido a lo largo de la tradición literaria, el Artista de Yuri Herrera crea su arte bajo la convicción de que todos tenemos una historia que contar, y el oficio del escritor radica en encontrar la palabra precisa para hacerlo. No importa si lo narrado es verificable o no; se trata de exhibir algunas verdades que, pese a ser también parciales, hablan de la naturaleza del ser y los vericuetos de la condición humana. De este modo, Trabajos del reino no solo despliega la locura a la que arrastra el poder, sino también sugiere cómo la ambición por lo prohibido mueve los deseos más íntimos, incluso cuando en estos va implícita una autocondena de muerte.

Es importante mencionar que, así como Eduardo Antonio Parra ha justificado el afán de los autores mexicanos por delatar un contexto nacional, los sonidos e imágenes recuperadas por Yuri Herrera en Trabajos del reino demuestran que se puede hablar de lo que sucede solo atrapando en la literatura - como en su momento lo consiguió Juan Rulfo - eso que caracteriza lo humano y que sobrepasa cualquier guiño referencial. Tal actitud narrativa sostiene a Herrera como uno de los narradores más sólidos de su generación.

\section{Bibliografía}

ÁVILA, Carlos: "La utilidad de la sangre en diálogo con Trabajos del reino de Yuri Herrera", Nueva $\quad$ Sociedad, $238 \quad$ (2012), 148-158, http://132.248.9.34/hevila/Nuevasociedad/2012/no238/13.pdf, 31/08/2016.

CARRASCO MANCHADO, Ana Isabel (2006): Isabel I de Castilla y la sombra de la legitimidad. Propaganda y representatividad en el conflicto sucesorio (1474-1482). Madrid, Sílex Ediciones.

FLORES, Enrique (2013): Rimas malandras del narcocorrido al narco rap. México, Universidad Nacional Autónoma de México.

FORERO QUINTERO, Gustavo: "La novela de crímenes en América Latina: Hacia una caracterización del género", Lingüística y Literatura, 57 (2010), http://aprendeenlinea.udea.edu.co/revistas/index.php/lyl/article/viewFile/6295/7902, 31/01/2016. 
FUENTES, Carlos (1976): La nueva novela hispanoamericana. México, Joaquín Mortiz.

HERRERA, Yuri (2013): La transmigración de los cuerpos. Cáceres, Periférica.

HERRERA, Yuri (2010): Señales que precederán al fin del mundo. Cáceres, Periférica. HERRERA, Yuri (2008): Trabajos del reino. Cáceres, Periférica.

LEMUS, Rafael: "Balas de salva: Notas sobre el narco y la narrativa mexicana", Letras Libres, 2005, http://letraslibres.com/revista/convivio/balas-de-salva, 01/11/2012.

PARRA, Eduardo Antonio: "Norte, narcotráfico y literatura", Letras Libres, 2005, http://www.letraslibres.com/revista/convivio/norte-narcotrafico-y-literatura,

31/08/2016.

PIGLIA, Ricardo (2006): "Secreto y narración. Tesis sobre la nouvelle”. En El arquero inmóvil. Nuevas poéticas sobre el cuento. Ed. Eduardo Becerra. Madrid, Páginas de Espuma, 187-205.

(C) Raquel Velasco

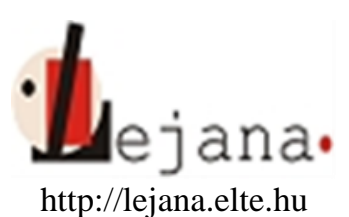

Universidad Eötvös Loránd, Departamento de Español, 1088 Budapest, Múzeum krt. 4/C

Recibido: 13 de junio de 2016

Aceptado: 27 de julio de 2016 